\title{
Kepercayaan dan Hegemoni dalam Cerpen "Makelar" Karya Sri Lima R.N. (Kajian Hegemoni Gramsci)
}

\author{
Fajrul Falah \\ Fakultas Ilmu Budaya, Universitas Diponegoro \\ fajrul.falah@live.undip.ac.id
}

\begin{abstract}
This study aims to express the trust and hegemony in the "Broker" short story by Sri Lima R.N. This research is motivated by the idea that language in fiction or short stories is meaningful and indicated not to be neutral. The language in the short story, became the media for sending message content to the author as a reflection of the social community referred to. The approach used in this study is the sociology of literature, specific to the study of Gramsci hegemony. The research method used is descriptive qualitative. Research data obtained from text, words, phrases, sentences, contained in short stories related to trust and hegemony. The research data is then described and expressed based on the approach used. The results of the study show that there was a change in the characteristics of Handoko's character as a broker who was initially good, become opportunist. Brokerage profession is used as a tool to hegemony the public to get profits. Community trust in brokers and people who are considered smart also grow. However, Handoko's figure was eventually protested by people who had used their services and failed. Handoko or brokers run away from the protests and demands of the people.
\end{abstract}

Keywords: community, trust, broker, power, and hegemony.

\section{Intisari}

Penelitian ini bertujuan untuk mengungkapkan kepercayaan dan hegemoni yang terdapat dalam cerpen "Makelar" Karya Sri Lima R.N. Penelitian ini dilatarbelakangi oleh pemikiran bahwa bahasa dalam fiksi atau cerita pendek penuh makna dan diindikasikan tidak netral. Bahasa dalam cerpen itu, menjadi media menyampaikan muatan pesan pengarang sebagai refleksi terhadap masyarakat sosial yang diacu. Pendekatan yang digunakan dalam penelitian ini adalah sosiologi sastra, spesifik pada kajian hegemoni Gramsci. Metode penelitian yang digunakan ialah deskriptif kualitatif. Data penelitian diperoleh dari teks, kata, frasa, kalimat, yang terdapat dalam cerpen tersebut yang terkait dengan kepercayaan dan hegemoni. Data penelitian itu kemudian deskripsikan dan diinterpresikan berdasarkan pendekatan yang digunakan. Hasil penelitian menunjukkan bahwa terjadi perubahan karakteristik tokoh Handoko sebagai makelar yang pada awalnya baik, menjadi oportunis. Profesi makelar dijadikan alat untuk menghegemoni masyarakat untuk mendapatkan keuntungan. Kepercayaan masyarakat terhadap makelar dan orang yang dianggap pintar pun tumbuh. Meskipun demikian, tokoh Handoko pada akhirnya 
diprotes oleh orang-orang yang pernah menggunakan jasanya dan mengalami kegagalan. Handoko atau makelar melarikan diri dari protes dan tuntutan masyarakat.

Kata kunci : masyarakat, kepercayaan, makelar, kekuasaan, dan hegemoni.

\section{Pendahuluan}

Manusia umumnya akan melakukan berbagai cara untuk mencapai tujuan dan impian. Tujuan atau impian dalam konteks ini bisa berupa pekerjaan yang layak, jabatan tinggi, kesehatan, usaha lancar, hingga mendapatkan jodoh. Impian itu memiliki konsekuensi bagi individu untuk bekerja keras. Konsistensi cara yang dilakukan umumnya bergantung pada komitmen dalam mencapai impian itu. Sebagian ada yang berhenti sebelum impian tercapai setelah melakukan usaha seperlunya, sebagian yang lain mengharuskan impian tercapai dengan cara yang dilakukannya, baik cara atau usaha yang rasional sampai irasional. Tiap-tiap manusia atau individu memiliki cara masing-masing untuk mewujudkan tujuan dan impian tersebut. Persoalan yang kemudian muncul adalah apakah cara-cara yang dilakukan sebagian manusia untuk mencapai tujuan itu bersifat logis atau rasional, diterima secara akal sehat oleh masyarakat secara umum, atau justru sebaliknya memakai cara-cara bersifat kepercayaan-kepercayaan yang dianggap tidak lazim bagi sebagian individu.

Persoalan yang terkait interaksi antarindividu, kepercayaan, kepentingan, bahkan kekuasaan bisa ditemukan dalam narasi fiksi, yakni cerita pendek (short story). Cerita pendek (cerpen) tidak sekadar berupa fiksi yang menonjolokan estetika bahasa dan peristiwa, melainkan juga memiliki makna mendalam yang bisa diungkapkan dengan diantaranya melalui pendekatan sastra. Melalui pendekataan sastra, bahasa dalam cerpen bisa dimaknai di antaranya sebagai representasi atau motif pengarang. Motif pengarang itu bisa berupa kritik sosial, masyarakat yang diidealkan, bahkan perlawanan terhadap realitas yang ada. Tentu realitas dalam cerpen tidak sama persis sebagaimana realitas masyarakat yang diacu oleh pengarang. Motif dan realitas dalam fiksi yang dihasilkan pengarang, umumnya dipengaruhi oleh tingkat pendidikan (pengetahuan), geografis, ekonomi, dan aktifitas sosial pengarang. Salah satu cerpen yang diindikasikan memuat dan merefleksikan salah satu realitas masyarakat di Indonesia terkait kepercayaan, hubungan dan kepentingan antarindividu adalah cerpen "Makelar" karya Sri Lima R.N. (Lihat Falah: 2018). 
Cerpen "Makelar" dimuat di harian Analisa, Sumatera Utara, 12 Mei 2019. Cerpen itu menarik diteliti di antaranya realitas dalam cerpen seperti memotret salah satu realitas yang terjadi di Indonesia. Tokoh-tokoh dalam cerpen adalah Handoko dan Amir. Handoko memiliki posisi sebagai makelar, sedangkan Amir direpresentasikan sebagai orang pintar. Mengapa dalam cerpen tokoh-tokoh lain memosisikan Handoko dianggap penting. Banyak orang yang berkepentingan terhadap Amir, akan tetapi Handoko diindikasikan mendapatkan keuntungan. Mengapa pula banyak orang atau tokoh dalam cerpen yang memiliki impian atau hajat, dikaitkan dengan Amir dan Handoko. Bagaimana respon sosok Handoko dan Amir terhadap masyarakat yang memerlukannya. Kepentingan antarindividu seperti apa yang diperjuangkan sehingga keduanya cukup popular di kalangan masyarakat. Cerpen "Makelar" sekalipun secara space terbatas, namun konflik dan peristiwa dalam cerita bisa dikemas secara padat dan baik. Alur peristiwa dan makna dalam cerpen pun bisa diungkapkan dan dipahami. Selain alasan atau argumentasi bahwa peristiwa dalam cerpen dianggap menarik dan diterbitkan relatif baru (12 Mei 2019), penelitian terkait cerpen "Makelar" belum ditemukan. Hal itu penulis buktikan berdasarkan penelusuran melalui internet dan jurnal di doaj.org, dengan memasukkan kata kunci "cerpen makelar". Meskipun demikian, ada penelitian-penelitian yang terkait dengan perpektif kajian hegemoni sebagai berikut.

(1) Falah (2018) menggunakan perspektif hegemoni Gramsci untuk mengkaji novel Ayat-Ayat Cinta Karya Habiburrahman el Shirazy. Fokus penelitian itu hegemoni dan ideologi yang dijalankan pada tokoh utama terhadap tokoh-tokoh lainnya yang terdapat dalam novel. Hasil penelitian mengungkapkan ideologi keagamaan menjadi faktor penentu hegemoni bisa dijalankan dengan baik (Lihat Falah, 2018). Penelitian lain, (2) Falah (2018) menganalisis novel Ketika Cinta Bertasbih Karya Habiburahman dengan pendekatan hegemoni Gramsci. Fokus penelitian ini mengungkapkan bentuk hegemoni dan ideologi yang terdapat dalam novel tersebut. Hasil analisis menunjukkan tokoh utama Azam dan Anna mampu menjalani kehidupannya dengan baik karena percaya dan taat terhadap nilai-nilai agama yang dianutnya (Lihat Falah, 2018).

Penelitian-penelitian yang telah disebutkan itu memakai perspektif hegemoni dengan objek material berbeda. Peneliti akan mengkaji cerpen "Makelar" dengan perspektif hegemoni Gramsci. Penelitian ini bertujuan untuk mengungkapkan kepercayan dan hegemoni yang terdapat dalam cerpen tersebut. Selain itu, sebagai pijakan awal akan 
diungkapkan karakteristik tokoh utama dalam cerpen itu. Oleh sebab itu, pada landasan teori akan diuraikan teori struktural fiksi lebih spesifik tokoh, kemudian dijelaskan pula terkait kepercayaan dan hegemoni Gramsci.

Tokoh dalam fiksi merujuk pada orang atau pelaku cerita. Adapun karakteristik tokoh lebih ditujukan atau diartikan sebagai perwatakan tokoh. Tokoh dalam fiksi dapat dikategorikan dalam beberapa penamaan seperti tokoh protagonis, utama, berkembang, dan tipikal. Berdasarkan peran pentingnya tokoh dalam cerita, dinamakan tokoh utama dan tambahan. Tokoh utama merujuk pada intensitas tokoh dan peran yang disandang ckupu signifikan dibandingakan tokoh-tkoh lainnya (Lihat Nurgiyantooro, 2013: 246-258). Karakteristik tokoh ditujukan untuk mengungkapkan peran tokoh dalam cerpen "Makelar" sebelum masuk ranah kepercayaan dan hegemoni. Kepercayaan merupakan modal sosial yang dimiliki individu dalam masyarakat. Individu yang sudah memiliki modal sosial itu dipercaya dianggap mampu memberikan pengaruh dan pertolongan saat dibutuhkan. Proses negosiasi atau kerjasama yang berlandaskan kepercayaan cenderung bisa diminimalisir. Kepercayaan masyarakat terhadap “orang yang dianggap pintar” yang memiliki kemampuan irasional berpotensi dimanfaatkan sebagian orang untuk mendapatkan keuntungan (Lihat juga Setyawati et al., 2010).

Konsep hegemoni Gramsci tidak terrbatas pada bidang pemerintahan atau politik, melainkan juga kekuasaan kelas sosial tertentu terhadap kelas sosial lainnya. Kepemimpinan hegemoni lebih didominasi melalui persetujuan, bukan paksaan. Kepemimpinan hegemoni dilakukan dengan mekanisme politis dan ideologis (Lihat Simon, 2001:21; Kurniawan, 2012: 71-73; Fajrul, 2018: 353). Konsep hegemoni yang terkait dengan cerpen yang akan dianalisis adalah kekuasaan yang dimiliki tokoh satu terhadap tokoh lainnya yang diterima secara sadar atau sukarela. Tokoh atau individu melakukan tindakan sesuai dengan apa yang diyakini dan dianggap benar, sekalipun kebenaran itu bersifat relatif dan sarat motif tertentu seperti ekonomi dan kekuasaan. Ada kelas sosial tertentu yang mendapatkan keuntungan dalam proses hegemoni.

\section{Metode Penelitian}

Penelitian ini merupakan jenis penelitian kepustakaan, bukan penelitian lapangan (field research). Data penelitian diambil melalui studi pustaka. Objek material penelitian ini 
adalah cerita pendek (cerpen) berjudul "Makelar" karya Sri Lima R.N. Adapun objek formal penelitian ini adalah kepercayaan dan hegemoni dalam cerpen itu. Pendekatan yang dipakai masuk ranah sosiologi sastra, spesifik hegemoni Gramsci. Metode penelitian yang dipakai untuk mengkaji cerpen "Makelar" adalah deskriptif kualitatif. Langkah kerja penelitian ini yaitu, pengumpulan data, analisis, dan penayjian atau hasil. Taha pengumpulan data dilakukan dengan cara membaca dengan cermat cerpen itu, kemudian menandai kata, frase, kalimat dalam cerpen yang relevan dengan objek formal dan kajian penelitiaan, yakni kepercayaan dan hegemoni. Data yang didapatkan itu kemudian dianalisis dengan pendekatan yang dipakai dengan cara diinterpretasikan dan dideskripsikan. Hasil analisis penelitian kemudian disajikan secara deskriptif-naratif.

\section{Hasil dan Pembahasan}

Bab analisis terdiri atas tiga subbab, yaitu sinopsis, karakteristik tokoh, dan kepercayaan serta hegemoni yang terdapat dalam cerpen "Makelar" karya Sri Lima R.N. Sinopsis dicantumkan dan dipaparkan lebih awal untuk memudahkan analisis selanjutnya.

\section{Sinopsis Cerpen "Makelar"}

Cerpen "Makelar" karya Sri Lima R.N, memuat kisah antara tiga kelompok atau golongan orang. Ketiga kelompok itu, pertama orang yang dipercaya dan dianggap pintar dalam dunia ghaib, kedua orang yang butuh dan percaya pada orang pintar tersebut, dan ketiga orang yang menjadi perantara dua kelompok orang tersebut. Tokoh yang dianggap pintar dalam dunia ghaib, memiliki kelebihan mampu membantu perjodohan, membaca mimpi, bahkan masa depan. Tokoh perantara bernama Handoko. Handoko tinggal satu desa bersama orang yang dianggap pintar, sehingga ia sering diminta tolong dan diberi hadiah oleh orang-orang yang menjadi pasien atau berkepentingan. Handoko secara garis keturunan, masih tergolong kerabat dengan orang pintar itu sehingga memudahkan dalam proses interaksi keduanya.

Handoko oleh sebagian masyarakat sekitar merupakan tokoh yang dianggap baik karena mau menolong teman dengan cara mengantarkan ke orang pintar dan tidak mau menerima imbalan. Pasien atau rekan Handoko yang diantarkan ke orang pintar memberikan testimoni keberhasilan dan menceritakan kepada orang-orang lain, sehingga nama Handoko semakin dikenal. Orang-orang di kota semakin banyak yang menghubungi dan order pada Handoko. Handoko pun semakin banyak menerima imbalan dari orang- 
orang yang memakai jasa perantaranya. Handoko yang dilabeli makelar, awalnya menolak segala bentuk pemberian hadiah yang diberikan oleh rekannya. Akan tetapi, ia kemudian menerimanya.

Handoko dalam "Makelar" dikisahkan cukup dominan, bahkan jika dibandingkan tokoh orang pintar bernama Pak Amir apalagi tokoh lainnya. Handoko pada awalnya tidak senang dan takut dosa sebagai makelar yang diberi imbalan, kemudian berubah diterima sepenuh hati. Keadaan berubah manakala orang-orang yang berkepentingan kepada Pak Amir tidak melalui Handoko lagi. Handoko semakin berharap imbalan, akan tetapi pasien justru semakin menjauh. Keadaan surut seperti itu membuat Handoko menemui Pak Amir, meski tidak diterima dengan baik. Diakhir cerita, orang-orang yang berkepentingan terhadap orang pintar melalui jasa Handoko ramai-ramai mendatangi sang makelar. Handoko tahu kemudian melarikan diri dari orang-orang yang pernah diantar Handoko dan gagal mewujudkan keinginannya, diantaranya menjadi calon legislatif (caleg).

\section{Karakteristik Tokoh Handoko}

Karaktersitik tokoh difokuskan dan dibatasi pada intensitas tokoh yang muncul dalam cerpen "Makelar" karya Sri Lima R.N. dan peran tokoh tersebut. Ada tiga tokoh dalam cerpen tersebut yang menjadi pusat penceritaan, yakni tokoh Handoko (makelar), Pak Amir (orang pintar) dan masyarakat secara luas. Analisis difokuskan pada tokoh Handoko. Handoko merupakan tokoh utama dalam cerpen "Makelar". Berdasarkan intensitas kemunculan tokoh, Handoko muncul lebih sering dibandingkan dengan tokoh Amir dan masyarakat. Tokoh Handoko disebut sampai 29 kali di dalam cerpen, bandingkan dengan tokoh Amir yang hanya disebut 2 kali.

Dilihat dari segi pusat pengisahan, Handoko menjadi subjek dan objek dalam narasi cerpen itu. Handoko sebagai subjek, ia yang memicu jalanya cerita sampai akhir, termasuk konflik antartokoh. Sebagai objek, ia menjadi sorotan tokoh-tokoh lainnya dalam cerpen. Dua peran Handoko itu signifikan dalam cerpen sehingga sebagian besar cerita dalam cerpen tidak bisa dipisahkan dari Handoko. Karakteristik Handoko pada awalnya merupakan sosok yang baik hati dan tulus dalam membantu masyrakat sekitar untuk diantarkan kepada orang pintar. Akan tetapi, sosok itu kemudian berubah menjadi pamrih dan berharap imbalan atas bantuannya, "Hadiah yang tadinya ditolak, jumlahnya lama kelamaan makin meningkat, kini diterimanya sepenuh hati” (Makelar, 2019:2). Perubahan 
karakter tersebut pada akhirnya tidak disenangi masyarakat dan menjadi kerugian bagi Handoko.

\section{Kepercayaan terhadap Orang Pintar}

Kepercayaan individu terhadap orang yang dianggap pintar terdapat dalam cerpen "Makelar" Karya Sri Lima R.N. Kepercayaan itu dianggap berlebihan karena orang-orang meyakini bahwa orang pintar mampu menafsir mimpi dan mewujudkan usaha yang diimpikan. Saat satu pasien atau klien ditafsir atau diterawang masa depannya secara baik dan memuaskan, testimoni itu kemudian tersiar di beberapa daerah dan kota dekat orang pintar itu tinggal. Kepercayaan terhadap orang pintar pun tumbuh sighnifikan baik dari dalam maupun luar desa. Motif masyarakat atau beberapa individu pun beragam, umumnya urusan ekonomi, pekerjaan, dan jodoh. Masyarakat semakin percaya terhadap orang pintar hal itu dibuktikan bahwa rata-rata dari mereka puas terhadap tafsir orang pintar dan mendatanginya berulangkali. Selain itu, mereka juga melihat secara langsung dan jelas bahwa orang pintar itu dianggap sakti yang memiliki ilmu kanuragan yang tahan bacok dan perut serta lidahnya tidak mempan ditusuk dan disayat sebilah keris. Orang pintar itu memiliki asisten yang bernama Handoko yang berperan sebagai makelar (Lihat, Makelar: 2019: 2).

\section{Kepercayaan terhadap Makelar}

Masyarakat yang memiliki kepentingan mendapatkan akses ke orang pintar melalui jasa makelar tokoh Handoko. Sebagian masyarakat sebagian besar justru lebih berurusan dan berinteraksi terhadap Handoko dibandingan sosok Amir. Servis baik yang dilakukan Handoko terhadap para tamu orang pintar, membuat ia mendapatkan kepercayaan. Tiap hari jumlah tamu yang meminta jasa Handoko semakin meningkat, "Hampir setiap hari hp lelaki itu berdering. Panggilan dari orang-orang yang memerlukan jasanya dalam memilihkan orang pintar yang tepat di kampungnya atau di kampung sebelah atau sebelahnya lagi” (Makelar, 2019:2). Kepercayaan seperti itu membuat Handoko mendapatkan keuntungan yang didapatkan dari para tamu. Para tamu mudah memberikan hadiah terhadap Handoko. Mereka pun tidak mengkritisi dengan cara mencari tahu bagaimana profil dan latar belakang Handoko. Dalam konteks ini kepercayaan mampu mereduksi individu untuk berpikir kritis apalagi menaruh kecurigaan. Sekalipun dalam 
konteks ini Handoko bukan menjadi tujuan utama, namun ia memiliki peran signifikan sebagai penghubung para tamu yang dianggap berhasil mewujudkan hajat atau keperluan melalui orang pintar itu.

\section{Hegemoni Peran Makelar}

Peran makelar yang disandang Handoko dimanfaatkan betul olehnya untuk meraup keuntungan. Peran Handoko semakin kuat karena ia mampu melayani para tamu dengan cara menunjukkan jalan dan mengantarkan kepada orang pintar secara baik. Handoko memiliki posisi yang lebih tinggi dan menguntungkan daripada masyarakat atau para tamu. Meskipun demikian, para tamu tidak merasa dimanfaatkan atau direndahkan posisinya oleh Handoko. Dalam konteks ini hegemoni yang dijalankan Handoko berjalan baik, relasi antara dirinya dengan klien atau tamu pun harmonis. Hal itu karena keduanya saling membutuhkan dan menguntungkan (mutualisme). Klien butuh diantarkan ke orang pintar untuk mewujudkan hasrat acau cita, sedang Handoko berharap dan mendapatkan imbalan atas jasa sebagai makelar.

Bisnis atau praktik semacam itu semakin berkembang karena banyak tamu atau klien cocok, baik pada jasa Handoko maupun penerawangan orang pintar itu. Hidup di lingkungan dan memiliki hubungan kerabat dengan orang pintar itu membawa kebaikan pada Handoko. Jika sedang musim pemilihan umum (pemilu), Handoko seperti mendapatkan durian runtuh, "Sejak itu mengalirlah kabar dari mulut ke mulut kawankawan Handoko di kota. Kalau butuh jasa orang pintar hubungi saja dia. Seperti semut mengerubungi gula yang tumpah di atas meja, ada saja yang datang kepada Handoko untuk dipertemukan dengan orang pintar di daerahnya" (Makelar, 2019: 2). Kutipan tersebut menunjukkan bahwa peran makelar mampu membuat taraf dan tarif hidup Handoko meningkat. Handoko menjadikan peran makelar sebagai profesi utamanya. Profesi yang cenderung tidak mengeluarkan modal benda dan minim berisiko akan kerugian, melainkan sekadar modal jasa atau layanan. Orang-orang atau klien dengan sukarela atau tanpa paksaan memberikan sebagian harta atau benda kepada Handoko.

\section{Hegemoni Ekonomi}

Praktik makelar sarat motif ekonomi yang dijalankan Handoko pada akhirnya tidak berjalan mulus. Sebagaimana bisnis atau pasar yang bisa mengalami fase pasang dan surut, 
profesi makelar Handoko pun demikian. Para tamu yang biasa menjadi klien Handoko perlahan tidak menggunakan jasanya lagi karena langsung menuju kepada orang pintar itu. Keadaan seperti itu membuat order dan penghasilan Handoko menurun dan mulai meragukan praktik makelar orang pintar yang selama ini ia jalani, "Dia bukannya senang jadi makelar klenik begitu, kerjasama dalam kemusyrikan sama berdosanya dengan melakukannya" (Makelar, 2019:2). Kutipan tersebut menunjukkan bahwa apa yang ada dalam hati Handoko berbeda dengan tindakan yang ia lakukan. Pada satu sisi ia tidak ingin terlibat jauh sebagai penghubung kepada orang pintar, sisi lain ia mendapatkan keuntungan berupa uang atau benda dari para tamu yang memakai jasa untuk diantarkan kepada orang pintar. Pada konteks inilah hegemoni ekonomi berperan, motif ekonomi memiliki kuasa terhadap keputusan yang diambil Handoko, sekalipun sedang dalam musim paceklik (surut) sebagai makelar, ia masih tetap bertahan.

Kondisi paceklik yang melanda Handoko membuatnya berpikir dan melakukan tindakan menemui orang pintar itu untuk bernegosiasi sekaligus mencari solusi ekonomi. Handoko yang terus berharap imbalan dari tamu meskipun perlahan tapi pasti semakin menurun, justru diabaikan dan mendapatkan penerawangan bahwa akan ada hal tidak baik yang akan menimpanya. Akan tetapi, kuasa ekonomi yang sudah melekat pada diri mampu menolak pembacaan orang pintar yang dipercayai oleh para klien-klienya sebelumnya itu. Hal itu dibuktikan sebagaimana kutipan berikut, "Akan ada sesuatu yang kurang baik menantimu di hadapan". Handoko mati kata. Dua orang pintar mengatakan hal yang sama." (Makelar, 2019:4). Motif ekonomi mampu menghegemoni dirinya untuk tidak berpikir rasional. Profesi makelar riskan terancam mengingat prediksi orang pintar berpotensi besar meleset. Peran makelar pun menjadi bumerang seperti senjata makan tuan, ia diprotes dan didemo oleh orang-orang yang pernah memakai jasa makelarnya yang kemudian gagal. Handoko menjadi sasaran utama bagi orang-orang yang kecewa terhadap hasil penerawangan orang pintar yang tidak benar atau menghasilkan. Handoko berhasil lari dari kejaran dan demo yang dilakukan masyarakat pengguna jasanya.

\section{Simpulan}

Cerpen "Makelar" Karya Sri Lima R.N. yang diterbitkan di harian Analisa merefleksikan persoalan terkait praktik dan kepercayaan terhadap orang yang dianggap pintar. Cerpen itu menitikberatkan bukan pada praktik orang yang dianggap pintar dan bisa memenuhi hajat 
orang banyak, melainkan pada pihak ketiga, yaitu orang yang berperan sebagai penghubung atau perantara antara orang yang berkepentingan dengan orang pintar itu. Perantara tersebut lebih dikenal dengan nama makelar yang juga menjadi judul cerpen. Sosok makelar yang dikenal dengan Handoko mengalami perubahan karakter. Tokoh Handoko yang awalnya baik hati, suka menolong dan tidak menerima imbalan atas jasa mengantarkan orang-orang yang berkepentingan kepada orang yang dianggap pintar, akhirnya mengharapkan imbalan.

Tokoh Handoko (makelar) memanfaatkan sebagian orang-orang yang percaya terhadap orang yang dianggap pintar, sebagai objek atau pangsa pasar yang menghasilkan. Kepercayaan masyarakat baik di dalam maupun luar lingkungan Handoko, terhadap orang yang dianggap pintar, tumbuh singnifikan. Konsekuensi kepercayaan itu membuat Handoko semakin populer dan berpenghasilan. Handoko dalam konteks itu menjadi pihak yang menghegemoni sekaligus terhegemoni. Handoko pada satu sisi menghegemoni kepada orang-orang yang memiliki kepentingan atau impian melalui jasa makelar dan mendapatkan uang. Orang-orang dengan sukarela memberikan hadiah atau imbalan kepada Handoko. Sokok makelar itu pada sisi lain terhegemoni oleh orang pintar (Amir), ia menerima segala perlakuan Amir dan tidak berani melawannya sekalipun.

Pak Amir memiliki kuasa terhadap Handoko, Handoko pun menyadari sosok orang pintar itu menghasilkan pada dirinya. Dalam hal ini motivasi ekonomi atau uang mampu menghegemoni Handoko sehingga ia mengurungkan niat untuk berhenti menjadi makelar sebagaimana yang dikhawatirkan istrinya. Praktik makelar Handoko tidak berjalan mulus karena pada akhirnya orang-orang yang merasa tidak berhasil atau mendapatkan keuntungan protes terhadap dirinya. Pola dan praktik seperti itu dalam cerpen menujukkan bahwa posisi makelar dan percaya terhadap orang pintar yang dianggap mampu memenuhi hajat hidup orang (impian) berpotensi besar terhadap kegagalan. Dengan kata lain, jalur itu ditempuh bukan jalan pintas menuju kesuksesan, akan tetapi dibutuhkan kerja keras dan rasional tiap individu untuk mewujudkan apa yang diinginkan atau dicita-citakan.

\section{Daftar Pustaka}

Falah, F. (2018) 'Hegemoni Ideologi dalam Novel Ketika Cinta Bertasbih Karya Habiburrahman el Shirazy (Kajian Hegemoni Gramsci)', Nusa: Jurnal Ilmu Bahasa dan Sastra, 13(4), p. 533. doi: 10.14710/nusa.13.4.533-542. 
Falah, F. (2018). 'Hegemoni Ideologi dalam Novel Ayat-Ayat Cinta Karya Habiburrahman el Shirazy (Kajian Hegemoni Gramsci)', Nusa: Jurnal Ilmu Bahasa dan Sastra', 13(3), pp. 351-360.

Falah. F. (2018) 'Pertentangan dan Kesadaran Kelas Sosial dalam cerpen "Tikus Raskin" Karya Kartika Catur Pelita (Kajian Sastra Marxis)’, 487, pp. 487-496.

Kurniawan, Heru. 2012. Sosiologi Sastra: Teori, Metode, dan Aplikasi. Yogyakarta: Graha Ilmu.

Ndari, Sri Lima Ratna. 2018. “Makelar". Harian Analisa. Sumatera Utara. Diakses melalui https://lakonhidup.com/2019/05/12/makelar/ pada 20 Mei 2019 pukul 20.08 WIB.

Setyawati, G. et al. (2010) 'Modal Sosial dan Pemilihan Dukun dalam Proses Persalinan : Apakah Relevan ? Pendahuluan', 14(1), pp. 11-16.

Simon, Roger. 2001. Gagasan-gagasan Politik Gramsci. Terj. Kamdani dan Imam Baihaqi. Yogyakarta: Pustaka Pelajar. 